\title{
Physical and Biochemical Characteristics of Sharhabiel Reservoir water, NW Jordan
}

\author{
NAZEM M.EL-RADAIDEH \\ Department of Earth and Environmental Sciences, Faculty of Science, \\ Yarmouk University, Irbid-21163, Jordan. \\ http://dx.doi.org/10.12944/CWE.10.1.05
}

(Received: January 16, 2015; Accepted: Feburary 17, 2015)

\begin{abstract}
Jordan relies heavily on rainwater stored in reservoirs because it $h$ is e cremely limited alternative water resources. These reservoirs are essential for drinking wa $ə r$ and ir igation, so monitoring their water quality is extremely important. Variations in physical and bi hemic conditions were investigated at Sharhabiel Reservoir (Jordan). Water quality mo itr ing of Sha ......el Dam, from January to December 2013 indicates that the dam is subject to agricı. . al runoff. It also revealed that mineral dissolution, sediment load, rainfall evaporation and pumping, i the major contributors to variations in water quality. The water chemistry of the impounded Sharnat. "eservoir showed that $\mathrm{Na}, \mathrm{Ca}, \mathrm{Mg}, \mathrm{HCO}_{3}$, and $\mathrm{Cl}$ are the principal ions, reflecting $\mathrm{H}_{10}$. Jminance of calcareous weathering, with some contribution of silicates. The $\mathrm{pH}$ values showe $\mathrm{I}$ an irregular pattern with highest values observed in the spring months. Total dissolved solids (TDS Ca, $\mathrm{Mc}$ and $\mathrm{HCO}_{3}$ are primarily related to leaching and evaporation, with elevated levels that occh the winter months. In contrast, seasonal patterns in $\mathrm{Na}, \mathrm{K}, \mathrm{Cl}$, and $\mathrm{NH} 4-\mathrm{N}$ conte-1s showed decreased values in wet months. Peaks in $\mathrm{NO}_{3}-\mathrm{N}$ observed in winter are strongly asso later ith agricultural runoff. Changes in chlorophyll-a level were coincided with low ratio of TN to T, $B C D_{5}, \sim C O D$ peaks in spring corresponding with high algal growth. No significant changes in $\mathrm{m}$ st $\mathrm{O}$ physical and biochemical parameters with depth, probably due to shallow deptr , igh annum edimentation rate and heavy pumping rate in dry months. No available recordes "ta for long-term monitoring of Sharhabiel reservoir water to emphasize the self-purification capac. of dam.
\end{abstract}

Key words: Sha «, iel Dam, Nutrients, Physiochemical, Parameters-Jordan.

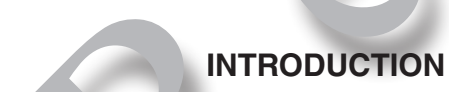

ter quaıı monitoring for the detection of trends, it. эcts, and improvements is further complicated $k$ scause the issues of concern and available resources are constantly changing (Hirsch et al., 2006). Jordan is one of the poorest countries in the MENA region in all types of natural resources, especially water. At the same time, Jordan is one of the fastest growing countries in population due to the high population growth rates combined with a rising erratic number of migrants and refuges from the different surrounding counties. The latest wage of refuges influx from Syria is expected to mount the pressure on ensuring the already limited water quantities in acceptable water quality. Hence, water reservoirs play an essential role in Jordan's water strategy especially for irrigation purposes (Saadoun, et al., 2008).

Increased erosion due to high winter runoff combined with higher water temperatures and more prolonged stratification in summer will, almost certainly, lead to widespread, climate-related eutrophication (Dokulil and Herzig 2009). Increased soil erosion and runoff will enhance nutrient load particularly from nitrogen and phosphorus to reservoir lakes. 
Nutrients, such as nitrogen, phosphorus, and silicate, in reservoirs are prerequisites for life and do not form an environmental problem. Sediments of surface water runoff from the surrounding land continue to supply organic nutrients and minerals to the Jordanian reservoir ecosystems. Atmospheric input from Mediterranean Sea as wind borne microorganisms is another source of the food base for growing larger plants and animals in addition to that human activities can also accelerate the rate at which nutrients enter Jordanian reservoir lakes. Two major nutrients are necessary for the development of aquatic life, namely nitrogen $(\mathrm{N})$ and phosphorus $(\mathrm{P})$, a third one, namely silicate is necessary for the development of diatoms (Rhee 1982).

Knowledge of the nutrient loading rates can shed some light on the potential productivity of the reservoir. In water affected by human made effluents, such as that of Shurhabiel Reservoir, high primary production resulting from an excessive load of nutrients may cause problems affecting water quality. Phytoplankton and nutrient dynamics are closely linked since nutrient uptake during alga' growth is the main process which removes dissolve nutrients from the water. Shurhabiel reservoir is one of the major water resources in NW uordan. Shurhabiel reservoir receives untreated $\mathrm{vvc}$ te water (Abu- Rukaha 2004; El-Radaideh et al., . 14). Monitoring the quality of surface 'ater in Jord in is very important because the reservc are essential sources for drinking water and other $u$.lestic and agricultural activities (Fa idi $t$. al., 2009). The present study aimed at investi 'r. Ing pl ysiochemical and biological parameters wh. - vailed in Shurhabiel Reservr ir ov he year 2013. This can help decisionmakc. to put sest solutions into practice.

\section{Catchmen ea and dam site setting}

The itchment's area is covered by limestone, marle and dolomite of Ajlun and Belqa group of upper Cretaceous age (Bender, 1974). It generally consists of steeply graded hillsides with the drainages in deeply incised valleys. The upper parts of the catchment area (located in Ajlun highs) have a maximum elevation of $+1050 \mathrm{~m}$ a.s.I with a natural forest cover and rich in loamy soil. They are dominated by a semi humid - humid climate with excess water during winter season. The lower part of the catchment area (located in Jordan River) is dominated by an arid climate characterized by a high temperature and an increase in evapotranspiration rate during summer. The yearly value for mean rainfall, mean annual runoff and flood runoff are $512.1 \mathrm{~mm}, 13.04 \mathrm{MCM}$ and $(9.6 \%-10 \%)$ respectively (Water Authority, 1989). The western part (Jordan River) is dominated by arid climate, with an annual rainfall of only $300 \mathrm{~mm} / \mathrm{yr}$. Potential evaporation ranges from $2050 \mathrm{~mm} / \mathrm{yr}$ in the west to $2200 \mathrm{~mm} / \mathrm{yr}$ in the east.

Sharhabiel Reservoir we ; cons. 'cted in 1966; it is a rock fill dam, $48 \mathrm{~m}$ in h/ rht, lo ated on ZeglabWadi in the northwect side of Jur uan, (Fig.1). The dam has a spillway, vhic , is a side overflow weir without a channel. The -pillway crest elevation is $86 \mathrm{~m}$ below me an sea leve. vater level was $94 \mathrm{~m}$ (spring 2013) . ' 'ow mean sea level. The deepest point recorded $w_{c} 11$ ? meters below mean sea level. It ic evident than the slope of the bed of the reser oir gradually drops down in elevation from the east $t$ vard th ? west where the Sharhabiel Dam is situatea. deepest area lies directly east of the ram. The average annual sediment accumulation rc of $0.046 \mathrm{MCM}$. The dam drains a catchment arf a of 106 square kilometers (Shatnawi, 2002) and « construction had a maximum storage capacity of 4.4 MCM (Arger, 1997; Macdonald, 1965a). Land use is agrarian with natural forests and a medium human population density.

The maximum length of the reservoir is $1500 \mathrm{~m}$ extending west-east with a width ranging between 35 and $500 \mathrm{~m}$ (Shatnawi 2002). A number of springs debouche along Ziqlab wadi with an annual discharge of about 5 MCM (Arger, 1997). In addition, Ziqlab wadi drains another $5 \mathrm{MCM} / \mathrm{yr}$ of floodwater (WAJ 1989). Ziqlab wadi is fed by a number of small tributaries such as Wadiat-Taiyiba and Wadi Abu Ziyad from the north and south, respectively, where slopes are steeper (El-Radaideh et al., 2014), (Fig. 1). The water discharged into the reservoir from the east by Ziqlab wadi, its semi muddy in the rainy storm events. The wadi flows in a steep sided valley and has an average gradient of $50 \mathrm{~m} / \mathrm{km}$ with two distinct series of falls $120 \mathrm{~m}$ and $30 \mathrm{~m}$ high respectively. The valley widens out into the Ghor (graben) at an elevation of $-175 \mathrm{~m}$. Field study shows, other surface materials in the southern Sharhabiel Reservoir area, consisting of 
fluvial, alluvial, and organic deposits, are generally stratified and moderately well sorted. Outwash materials consist mainly of rounded gravels mixed with sand and silt, such deposits usually occur at the lower portion of Ziqlab wadi catchment. According to JVA, (1965), the geological succession in the dam area can be described as a talus, alluvium, cap conglomerates with crystalline and oolitic/pisolitic limestone, red pebbly and sandy marls, lenticular calcareous conglomerates, crystalline limestone with some marlstones, glauconitic calcareous sandstone's, and chalk. The cap rocks which belong to the Plateau gravel group overlie the lower formation unconformable. The chalk and overlying formations appear conformable but a disconformity may exist however, as there is a marked change in lithology. The chalk is considered to belong to the upper white chalk member of the Belqa group (Fig.1).

\section{MATERIALS AND METHODS}

This study relies depends on 12 monthly surveys and findings from literatures (El-Radaideh et al., 2014) and data were obtained from the (JVA) Jordan Valley Authority to evaluate water quality the Sharhabiel Dam. Two sampling sites 'A1 and A2) were selected for investigation. A1 vas closer to the shore of the reservoir lake and $A 2 r$ resents the open area and the deepest roint at the re. -soir bed (Al-Ansari and Shatnawi, 2(. ' with water depth more than $16 \mathrm{~m}$, about $200 \mathrm{~m}$ frc site A1, (Fig. 1). The one-year monitorim data (2010) include the following:

- Firlemeasuremeı. il water temperature, $\rho \mathrm{H}, \mathrm{si}_{\mathrm{c}}$ ity, dissolved oxygen and conductivity ere r nasured in situ with water transparency u $r$ a Secciıl disc $(21 \mathrm{~cm})$ at each site and by us ramultiparameter portable instrument (WTW, Multiline F / SET-3).

- In order to investigate the vertical distribution of some of the changeable parameters under consideration, deeper samples at site A2 were collected at two meters interval. Surface water samples were collected in pre-cleaned polyethylene containers and transported to the laboratory in an ice-filled box for analysis. Samples were then refrigerated at $4{ }^{\circ} \mathrm{C}$ and analyzed within $48 \mathrm{~h}$ of sampling; water sampling and preservation were carried out according to APHA, (1998). Samples for chemical analysis of nitrate, phosphorous and silicate were filtered using Whatman millipore filters with 0.45 ìm pore size. Alkalinity was determined following the Standard Methods (APHA 1998). Surface water samples were also analyzed for $\mathrm{Na}$ and $\mathrm{K}$ (by flame photometer); $\mathrm{Ca}$ and $\mathrm{Mg}$ (by titration method); $\mathrm{HCO}_{3}$, (by ion chroma graphy); COD (by closed reflux, titrimetrı nethod); and chlorophyll-a (by fluorometric de. rmination). Samples were analyzed, duplic is with analytical uncertainty of les. han', \%.

\section{RESULTS A ND JISC.USSION}

Fluc "'ition of Waw. levels at Sharhabiel reservoir is thit ombined result of irregular inflow and outflow. Accc 'in' MWI (2009) water level of Shahr Reservoir showed a decreasing trend from spring through summer, with lowest levels that were easur din the dry summer months. These low levels o ․ reservoir water in the summer months vre primary attributed to increased consumption of $n-r$ for irrigation use and to high evaporation rate $d$, contributes to marginal erosion and sedimentation in the reservoir (HKJ-GTZ 2009; Branco et al. 2002) with potential release of nutrients and trace metals from sediments, usually during flood events, (Zhao et al. 2013; Fonsica et al., 2011). A wide fluctuation in water level, however, is a common feature in reservoir and affects their ecology through, an enhanced nutrient exchange between pelagic and littoral zones of the reservoir (Fonsica et al., 1993; 2010).

\section{Physical Monitoring Temperature}

Slight variation in surface water temperature between sampling site $\mathrm{A} 1$ and $\mathrm{A} 2$ can be attributed to the time of sampling (Fig.1, and Fig. 2, a). A mean air temperature of $28.2^{\circ} \mathrm{C}$ with a maximum of $39.5^{\circ} \mathrm{C}$ in July and minimum of $15^{\circ} \mathrm{C}$ in February, 2013 are consistent with the fact that the reservoir is situated in a Mediterranean subtropical to temperate climate. Owing to the rapid increase in air temperature in July a slight short thermal stratification developed in the reservoir and lasted until August (Fig 2, b). In 
addition to increasing the amount of solar radiation reaching the reservoir water's surface, removal of vegetation near dam and its catchment streams often results in increased erosion and increased amounts of sediments in the dam. The sediments absorb heat from sunlight rather than reflect it. This heats the water further.

Vertical gradients in temperature can be measured in deeper and shallower water systems, in May 2013, very weak thermal stratification was observed with an average of $2.5^{\circ} \mathrm{C}$ temperature difference recorded between surface and deeper layers (Fig. 2, b). More clear stratification developed in June 2013 , with an average of $4.0^{\circ} \mathrm{C}$ difference in temperature between surface and underlying water. Two layers of distinctive temperatures were recognized: the surface layer, 10 meters deep with an average temperature of $32^{\circ} \mathrm{C}$, and a second layer down to 16 meters depth with an average temperature of $28.7^{\circ} \mathrm{C}$ (Fig. 2, b). This slight stratification continued in July with an average of $3.40^{\circ} \mathrm{C}$ difference between the two layers.

The average difference in water temperature between surface water and th. reepest point measured $(16 \mathrm{~m})$ at site $\mathrm{A} 2$ was 4 and $3.40^{\circ} \mathrm{C}$ in June and July respectively, a differt. 'e which insured the presence of a weak the rocline, tween the upper layer and the lower lay ig. 3, b). The thermocline, howe' $\mathrm{CI}$, ras broken in August because of a change $n$ water temperature, and due to an excessive $\mathrm{pu}$ nin of water from the reservoir whic remarkably reduced water depth. Sharhabiel reser . ir can be considered monomictic where weak thermaı tification occurs once a year

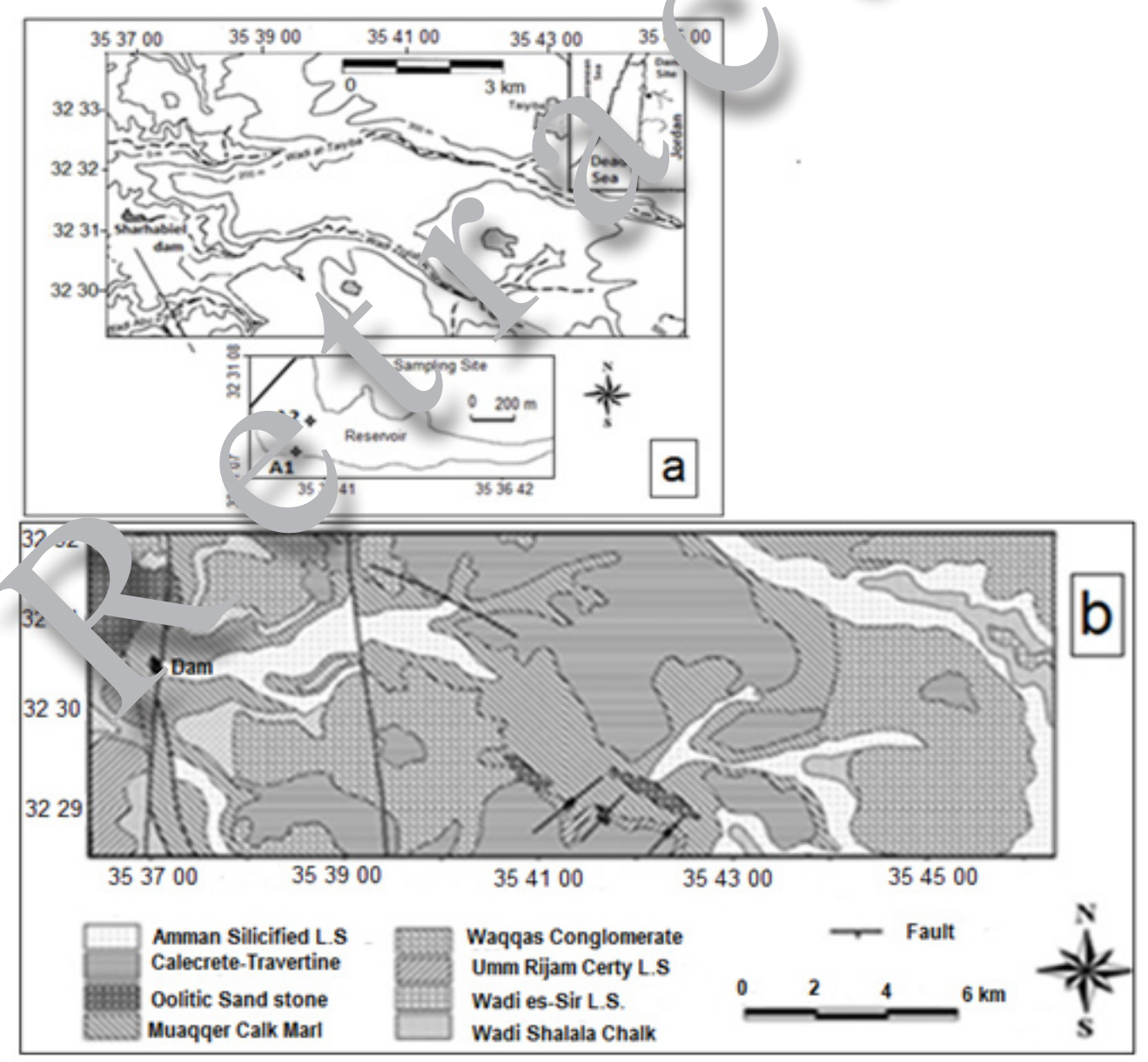

Fig.1: (a): Map of the study area with location of sampling points (A1 and A2) in Sharhabiel Reservoir. (b): Geologic map of the study area. 
during summer. Thermal stratification, however, is a common phenomenon in MENA regions. Similar water layering was recorded in King Talal reservoir and Wadi Al-Arab Dam in Jordan (Al-Handal \& Saadoun 2001, Saadoun et al., 2010). Similar conditions can also be observed in reservoirs located in subtropical and temperate regions (Temponeras et al.2000). Temperature gradients are set up due to the physical properties of water, where water is most dense at $16 \mathrm{~m}$ depth, ensuring that cooler waters will typically be found at the bottom of reservoir lake.

Temperature is important in aquatic reservoir because it can cause mortality and it can influence the solubility of dissolved oxygen (DO) and other materials in the water col umn. Photo inhibition due to the increase in the photoperiod in summer may lead to a marked decrease in chlorophyll-a content of the reservoir (Fig.3, a), while in winter when light is weak and daylight is short, the role of temperature on primary production was insignificant.

\section{Water Transparency}

Water transparency in t'ie re rvoir was relatively low during the study per, $x$. The I limum Secchi depth coincided with surface. - oduction in December 2013, whi... characterized by an increase in the phytoplar kt, $\mathrm{l}$ bior hass. The maximum secchi depth in June ret, ts th low phytoplankton density. The $n$ in Secchi aıc depth of $0.74 \mathrm{~m}$ may explain the wal turbidity in the reservoir that is derived from suspe, 'n phytoplankton, and partially from $t$ sc. suspended solids, which were kept at a minir um due to weak mixing and decreased water inflow -ia.2, ).

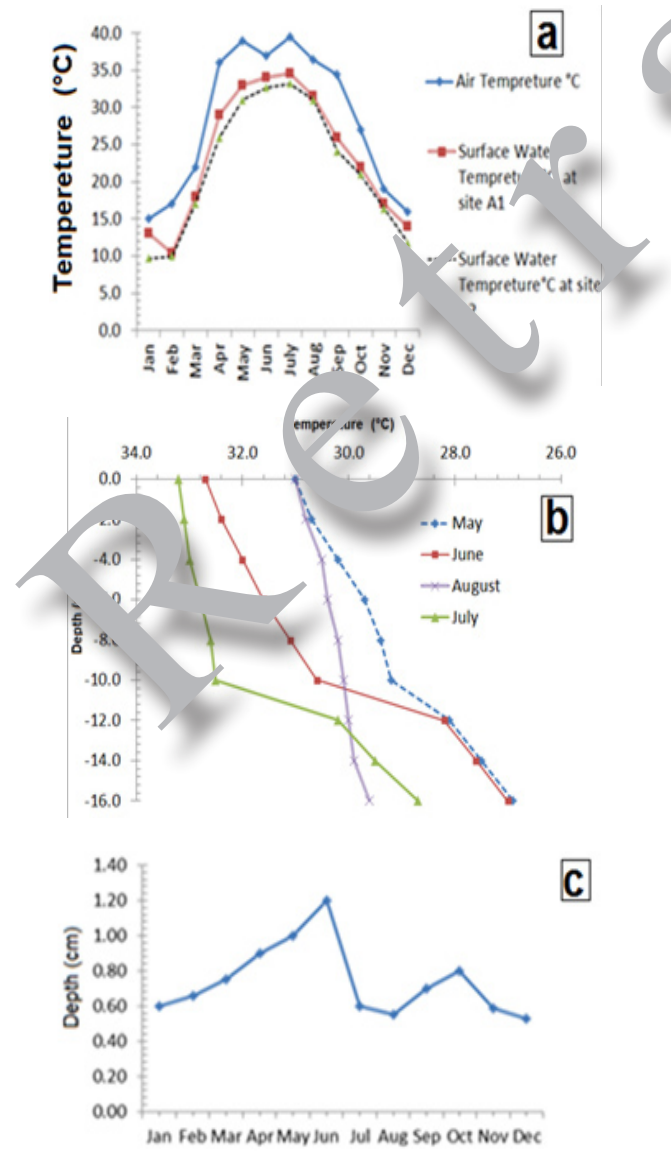

Fig. 2: (a) Air -water temperature, (b) Depth temperature profiles and (c) Water transparency at Sharhabiel Reservoir.

\section{'iochemical Monitoring}

Di Jlved Oxygen Levels

Water temperature had a remarkable effect on dissolved oxygen concentration in the Shrhabiel reservoir. Dissolved oxygen levels ranged from 6.05 to $8.7 \mathrm{mg}^{-1}$ I at site $A 2$, while the maximum value at site $A 1$ was $8.8 \mathrm{mg}^{-1}$ I with overall mean DO values at site $\mathrm{A} 2$ more than site $\mathrm{A} 1$ (Fig. 4,a).

The lowest DO values at both sites were in August 2013 (6.05 and $6.1 \mathrm{mg} \mathrm{l}^{-1}$ at site A2 and A1, respectively). In February, DO peaks during winter season at station site $\mathrm{A} 2$, as shown in figure 4, a. DO concentration diminished with depth from April through August. In April, dissolved oxygen concentration dropped from $7.8 \mathrm{mg} \mathrm{l}^{-1}$ at the surface to $4.1 \mathrm{mg} \mathrm{l}^{-1}$ at $16 \mathrm{~m}$ depth. In May, DO in the upper layer was $7.36 \mathrm{mg} \mathrm{l}^{-1}$ then dropped to $4.44 \mathrm{mg} \mathrm{l}^{-1}$ in the deepest water layer (Fig. 4, b).

\section{Chlorophyll-a - Nutrients \\ $\mathrm{P}-\mathrm{PO}_{4}$ mean level at site $\mathrm{A} 2$ was $0.54 \mathrm{mg}^{-1} \mathrm{I}$} and at site $A 1$ as $0.35 \mathrm{mg}^{-1} \mathrm{l}$, with minimum values of $0.16 \mathrm{mg}^{-1} \mathrm{I}$ recorded in October at both sites. Levels of $\mathrm{P}-\mathrm{PO}_{4}$ were high; with maximum concentrations of $1.1 \mathrm{mg} \mathrm{l}^{-1}$ and $0.8 \mathrm{mg} \mathrm{l}^{-1}$ found in June and May at sits $A 2$ and $A 1$, respectively (Fig.3,b). Concentrations of phosphorus in water are quite low; dissolved orthophosphate concentrations are usually not greater than 5 to $20 \mu g^{-1} 1$ and seldom exceed 100 


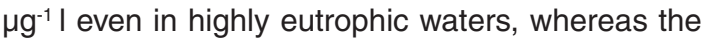
concentration of total phosphorus seldom exceeds $1000 \mu^{-1}$ I (Boyd 1976, Boyd 1990).

In discussing the correlation of different parameters with primary production, chlorophyll-a appears to be the closest factor in this regard and is widely used as an indirect measure of phytoplankton productivity (Voros and Padisak, 1991). Chlorophyll-a level can be an effective measure of trophic status and potential indicator of maximum photosynthetic rate and are a commonly used as a measure of water quality. It is an indicator of algal biomass (Forsberg \& Ryding1980; Cloot \& Ros1996) which is largely dependent on TP in freshwater (Dillon \& Rigler1974; Pridmore et al. 1985; Guildford et al. 1994). In lake level of phosphorous greater than 0.02 $\mathrm{mg}^{-1} \mathrm{I}$ can stimulate the growth of most types of green and blue green algae (Wetzel 1983). Chlorophyll- concentrations are seasonally high, suggesting phytoplankton blooms throughout the monitoring period. However moderate correlation coefficient between chlorophyll-a and TP levels ( $r=0.45$; Table1). Dodds $(2003,2006)$ indicated that TN-TP ratios are more accurate indicators of $/ 1$, rient limitation. Fluctuations in chlorophyll-a level wa closely tied to TN-TP ratio (Fig.4, a).

Excessive growth of algae (his .orophyll-a level) has nearly coinci eu vith a low ratio of TNTP (Fig. 3, a). This inc is ates th at chlorophyll-a is more stronglv related $t c{ }^{-}+{ }^{+}$in to $T N$, and that phosphorus is enerally the limiting factor for algal growth. Seasona reduction of algal growth, when TN-TP is still low, 1. " ates that nutrients may not be the Or "y variables regulating algae growth in the reser oir, but also light, temperature, low $\mathrm{CO}_{2}$, high $\mathrm{pH}$ an . un urbidity may promote cyanobacteria

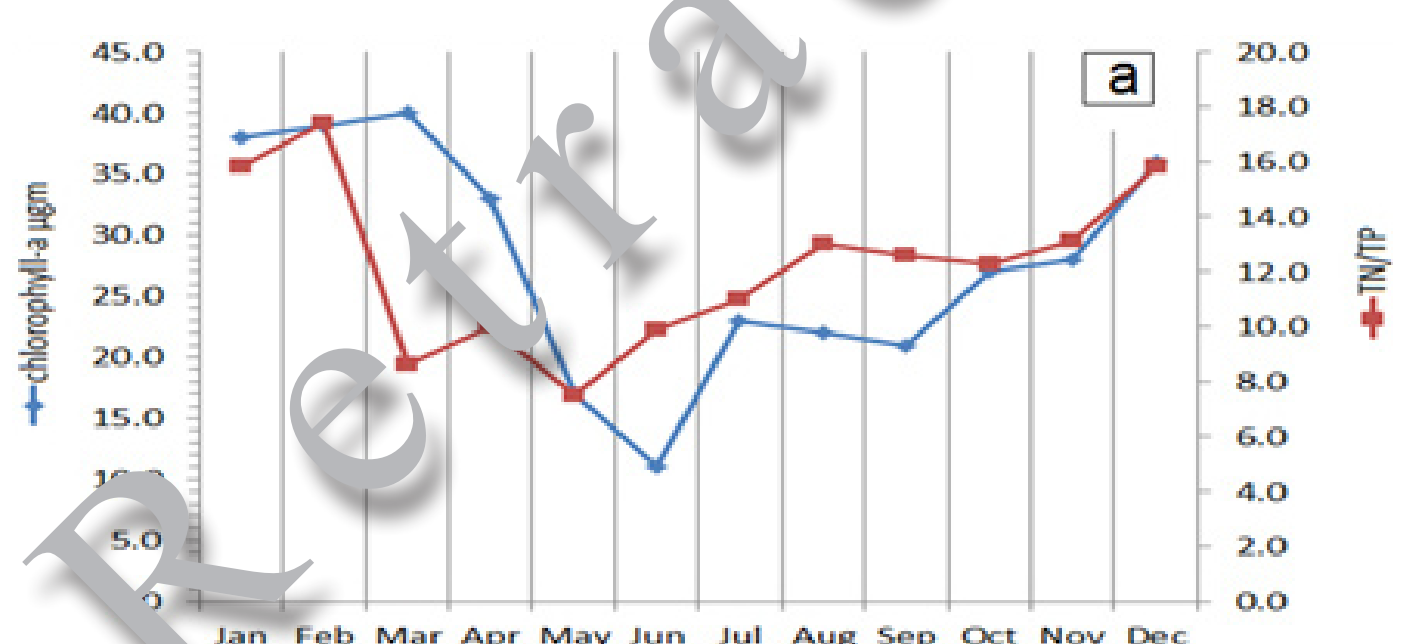

Jan Feb Mar Apr May Jun Jul Aug Sep Oct Nov Dec

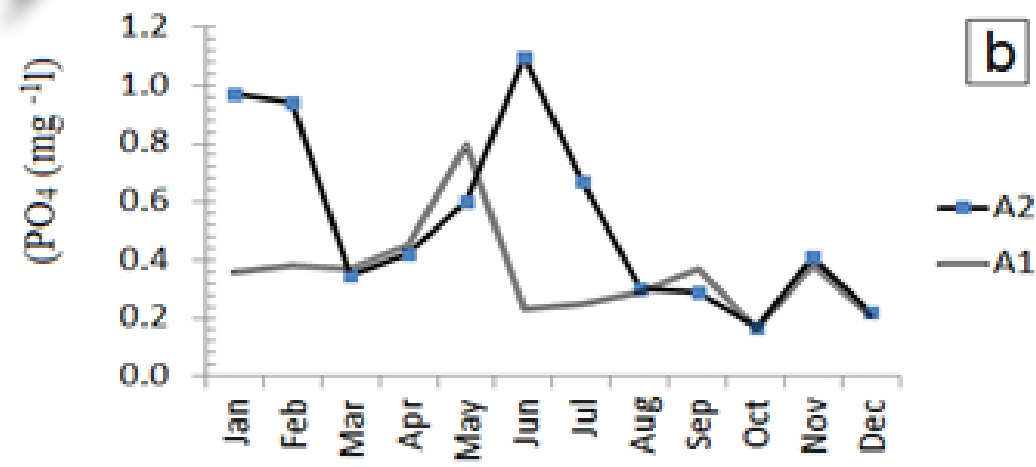

Fig.3: (a) Monthly variations in chlorophyll-a level with TN-TP ratio, (b) phosphorus ( $\mathrm{PO}_{4}\left(\mathrm{mg}^{-1} \mathrm{I}\right)$ concentration at sites $\mathrm{A} 1$ and $\mathrm{A} 2$ 
growth (Levine \& Schindler1999). Higher phosphorus concentrations were particularly corresponded to spring with months of most active microbial and algal growth. Nonpoint source pollutions are a major source of phosphorus to Sharhabiel dam water; phosphorus can potentially be released from the dam sediments through biological and chemical processes and mixed into the water column. (Madison1994; Fonsica 2011), very fine sediment (less than $63 \mathrm{im}$ ) is often chemically active. Phosphorus and metals tend to be highly attracted to the ionic exchange sites associated with iron and manganese positive relationship between suspended solids in water bodies and total phosphorus concentrations is demonstrated by Ongley (1996). Many toxic organic contaminants are strongly associated with silt, clay and organic materials transported by water to reservoirs (Boatman en 1999; Owens et al., 2005). Thus, sediments act an agent in the process of eutrophication and oxicir, n aquatic organisms.

Phosphorus is ISC fached from phosphate bearing strata of Ar ran si icified limestone

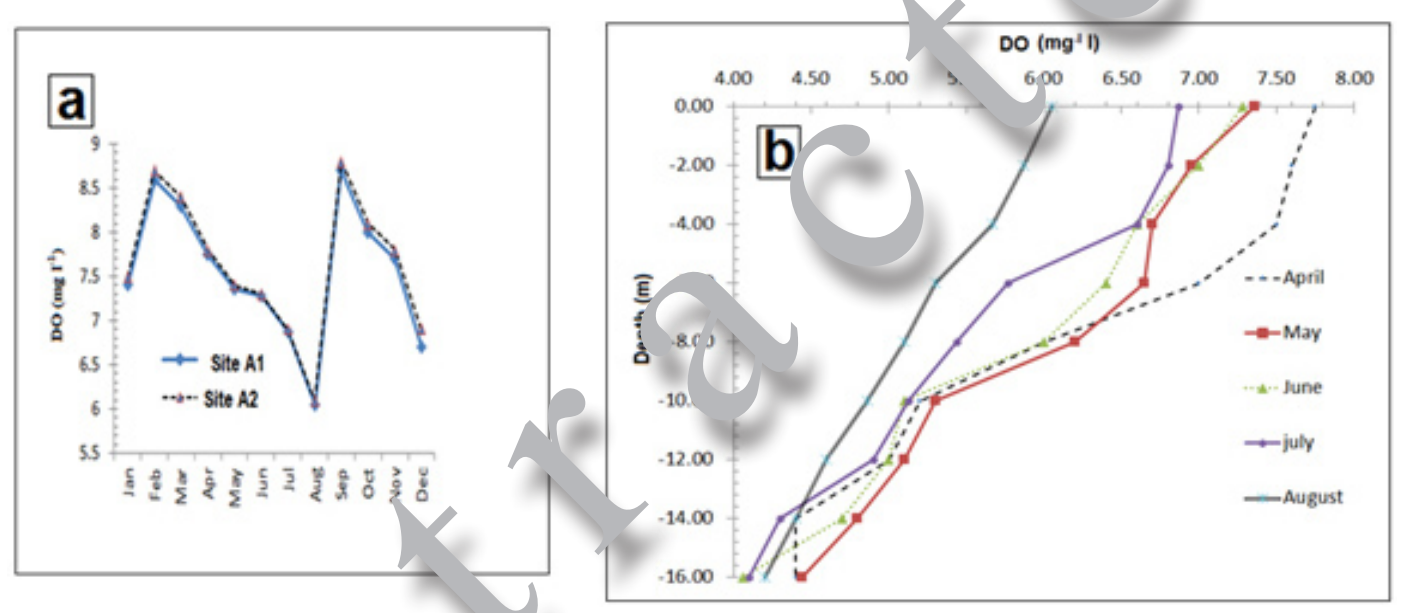

Fig. 4: (a) Water dissolv- 'oxygen in $\mathrm{mg}^{-1}$ I at sites A1 and A2 (b) Depth profiles of water dissolved r.xygen in $\mathrm{mg}^{-1}$ (April, May, June, July and August)

\begin{tabular}{|c|c|c|c|c|c|c|c|c|c|c|c|c|c|}
\hline & $\mathrm{nH}$ & $\begin{array}{l}\text {-nc } \\
\left(\mathrm{mg}^{-1} \mathrm{I}\right)\end{array}$ & $\begin{array}{c}\mathrm{Ca} \\
\left(\mathrm{mg}^{-1} \mathrm{I}\right)\end{array}$ & $\begin{array}{c}\mathrm{Mg} \\
\left(\mathrm{mg}^{-1} \mathrm{l}\right)\end{array}$ & $\begin{array}{c}\mathrm{Na} \\
\left(\mathrm{mg}^{-1} \mathrm{I}\right)\end{array}$ & $\begin{array}{c}K \\
\left(\mathrm{mg}^{-1} \mathrm{I}\right)\end{array}$ & $\begin{array}{c}\mathrm{Cl} \\
\left(\mathrm{mg}^{-1} \mathrm{I}\right)\end{array}$ & $\begin{array}{l}\mathrm{HCO}_{3} \\
\left(\mathrm{mg}^{-1} \mathrm{l}\right)\end{array}$ & $\begin{array}{l}\text { Total P } \\
\left(\mathrm{mg}^{-1} \mathrm{l}\right)\end{array}$ & $\begin{array}{c}\mathrm{NO}_{3} \\
\left(\mathrm{mg}^{-1} \mathrm{I}\right)\end{array}$ & $\begin{array}{l}\mathrm{NH}_{4}-\mathrm{H} \\
\left(\mathrm{mg}^{-1} \mathrm{l}\right)\end{array}$ & $\begin{array}{l}\text { BOD5 } \\
\left(\mathrm{mg}^{-1} \mathrm{l}\right)\end{array}$ & $\begin{array}{c}\text { COD } \\
\left(\mathrm{mg}^{-1} \mathrm{I}\right)\end{array}$ \\
\hline TDS & 0.08 & ren & & & & & & & & & & & \\
\hline $\mathrm{Ca}$ & -0.09 & 0.85 & & & & & & & & & & & \\
\hline $\mathrm{Mg}$ & -0.59 & 0.27 & 0.66 & & & & & & & & & & \\
\hline $\mathrm{Na}$ & -0.57 & 0.06 & 0.50 & 0.95 & & & & & & & & & \\
\hline $\mathrm{K}$ & -0.47 & 0.08 & 0.49 & 0.94 & 0.93 & & & & & & & & \\
\hline $\mathrm{Cl}$ & -0.41 & 0.10 & 0.54 & 0.94 & 0.96 & 0.98 & & & & & & & \\
\hline $\mathrm{HCO}_{3}$ & 0.00 & 0.81 & 0.89 & 0.59 & 0.40 & 0.52 & 0.52 & & & & & & \\
\hline Total P & 0.41 & 0.13 & 0.00 & -0.14 & -0.31 & 0.04 & -0.06 & 0.35 & & & & & \\
\hline $\mathrm{NO}_{3}-\mathrm{H}$ & -0.47 & 0.55 & 0.74 & 0.78 & 0.71 & 0.68 & 0.68 & 0.73 & -0.07 & & & & \\
\hline $\mathrm{NH}_{4}-\mathrm{H}$ & -0.32 & -0.91 & -0.65 & 0.04 & 0.27 & 0.17 & 0.17 & -0.67 & -0.39 & -0.28 & & & \\
\hline $\mathrm{BOD}_{5}$ & 0.65 & -0.47 & -0.74 & -0.90 & -0.83 & -0.74 & -0.74 & -0.58 & 0.36 & -0.83 & 0.13 & & \\
\hline COD & 0.74 & -0.35 & -0.59 & -0.78 & -0.75 & -0.56 & -0.58 & -0.33 & 0.63 & -0.68 & -0.02 & 0.94 & \\
\hline $\begin{array}{l}\text { chloro- } \\
\text { phyll-a }\end{array}$ & -0.15 & 0.53 & 0.68 & 0.63 & 0.46 & 0.60 & 0.56 & 0.74 & 0.45 & 0.61 & -0.43 & -0.49 & -0.30 \\
\hline
\end{tabular}



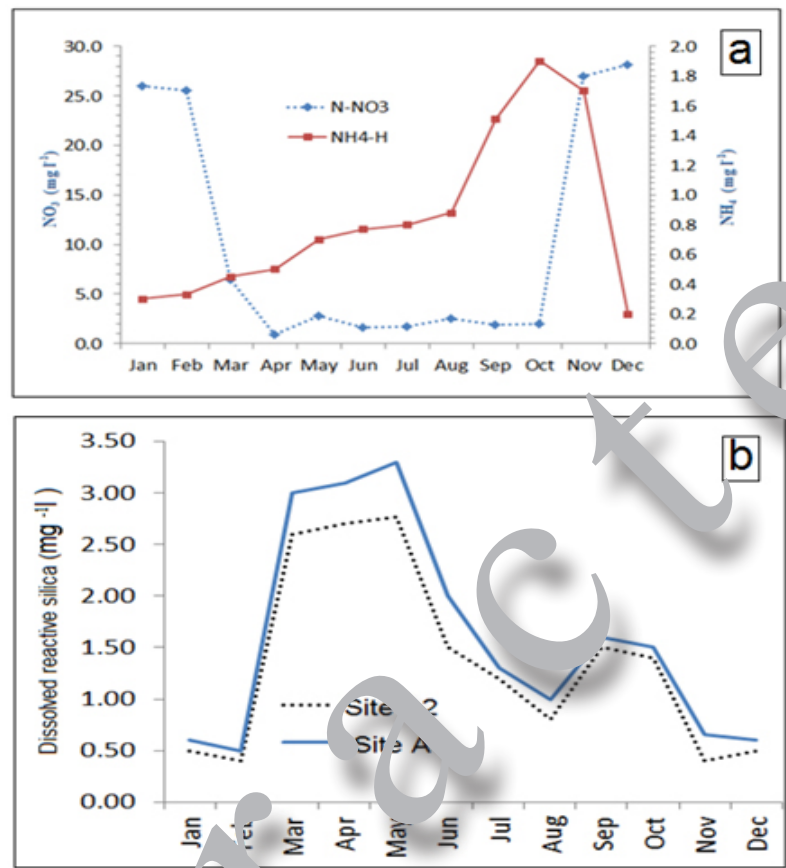

Fig. 5: (a) Distribution of $\mathrm{NC}-\mathrm{N}$ and $\mathrm{NH} 4$. concentrations of Sharhabiel Dam water during the study period ( $\omega)$ 'licate $(\mathrm{Si})\left(\mathrm{mg} \mathrm{l}^{-1}\right)$ concentration at sites A1 and A2
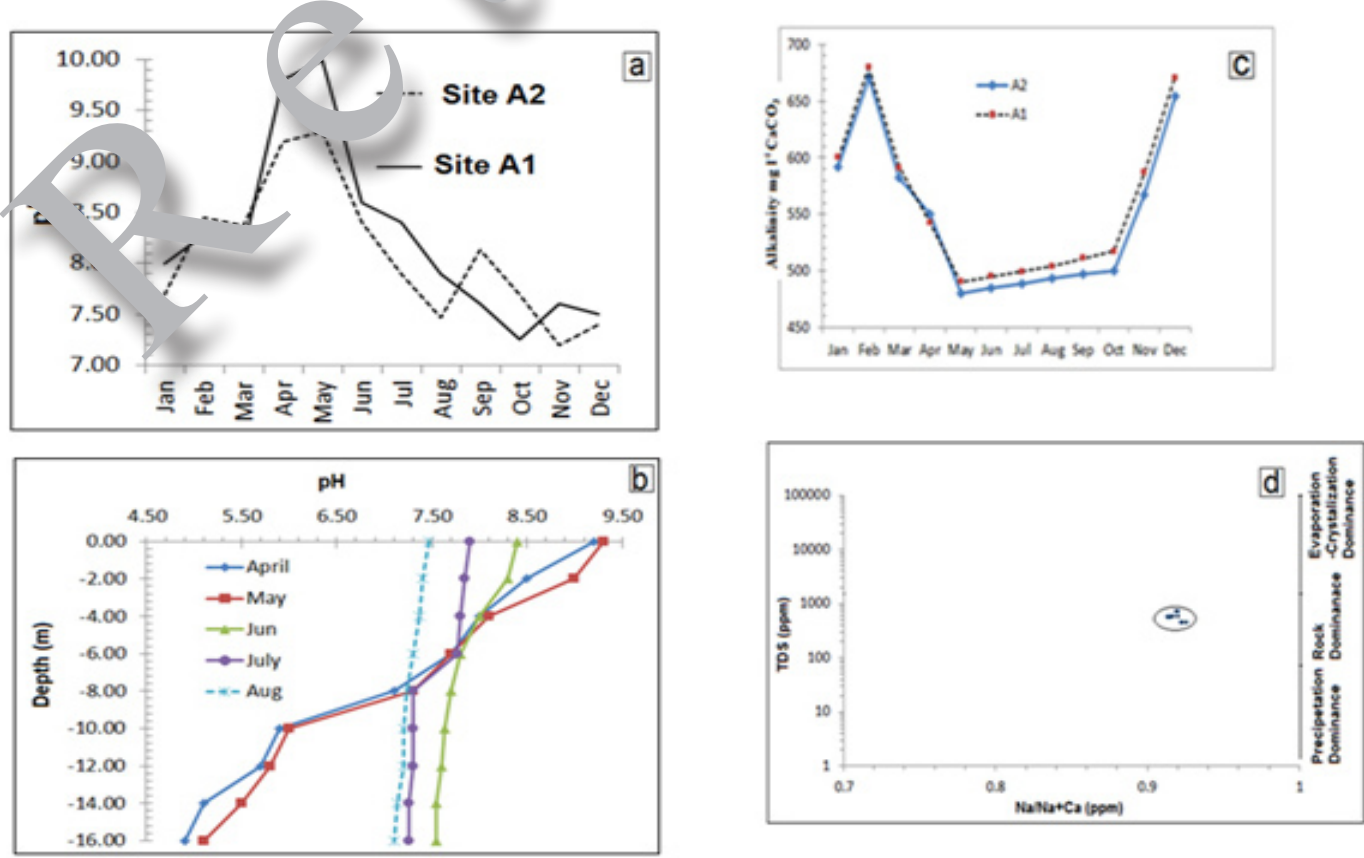

Fig. 6: (a) pH at sites A2 and A1 (b) Depth profiles of pH-April, May and June (c) Alkalinity in $\mathrm{mg}^{-1} \mathrm{I} \mathrm{CaCO}_{3}$ and (d) Plot of Sharhabiel Dam waters on Gibbs diagram 
Formation outcrops in the upper catchment (Fig.1). Other major sources of phosphorous are fertilizers and pesticides carried in agricultural discharge from the upper catchment soils. Phosphorus can enter freshwater from atmospheric precipitation (Wetzel, 2001; Soares et al., 2008). Based on chlorophyll-a classification of Forsberg\& Ryding (1980), Shrahabiel Reservoir is in a eutrophic to hypereutrophic condition. Trophic status of Sharhabiel dam water with regards to total phosphorus concentration is in hypereutrophic; where total phosphorus concentration $\left(0.35 \mathrm{mg}^{-1} \mathrm{l}\right)$ was more than $100 \mu^{-1}$ I . Based on the studies carried by Yang et al. 2008; Richardson et al. 2007; Cheng and Li 2006, the reservoir is excessively eutrophic because the mean of TP concentrations throughout the year 2113 is $0.353 \mathrm{mg}^{-1} \mathrm{I}$ greater than $0.3 \mathrm{mg}^{-1} \mathrm{I}$. Eutrophication has been reported in lake water when TP is greater than $0.3 \mathrm{mg}^{-1}$ or even at lower TP concentrations. Field observations indicate that the reservoir has been excessively eutrophic.

The average TSI (Trophic Status Index), (Carlson 1977) values ranged between 70 (in fall) to 80 (in spring), also indicating that the reservoir is excessive-eutrophic (Ferrier et al., 2001).

Mean reservoir $\mathrm{N}-\mathrm{NO}_{3}$ for both sites is 10.9 $\mathrm{mg}^{-1} \mathrm{I}$, with minimum and maximum concentrations of $1.0 \mathrm{mg}^{-1} \mathrm{I} \mathrm{N}$ and $31.3 \mathrm{mg}^{-1} \mathrm{I} \mathrm{N}$, at site $\mathrm{A} 1$. Which are higher than average content of most aquatic ponds 2.5 to $500 \mu g^{-1} 1$ (Boyd 1976). Nitrate-N concentrations increased remarkably during the wet months, with a remarkable $r$, were observed in November to February at both s. s (Fig.5, a, b), where the concentrations decrea seu approach its minimum values in the summe and ta rouths. Nitrate is closely linked to agricultu ' runc $f$ (Ferrier et al. 2001). More than 2 nor of the catcinment lands are used extensively for ar fricultural purposes and the increase in $\mathrm{NO}_{3}-$ conc ntrations may be due to leach no from $\mathrm{NC}_{3}$.. Izers. High-intensity rainfall gene.. 'v mobilizes more nutrient-laden sediment than lov intensity storm events (Basnyat et al.2nn).

NO $-\mathrm{N}$ enters Sharhabiel Dam probably from su. r. runoff and is removed either by algal

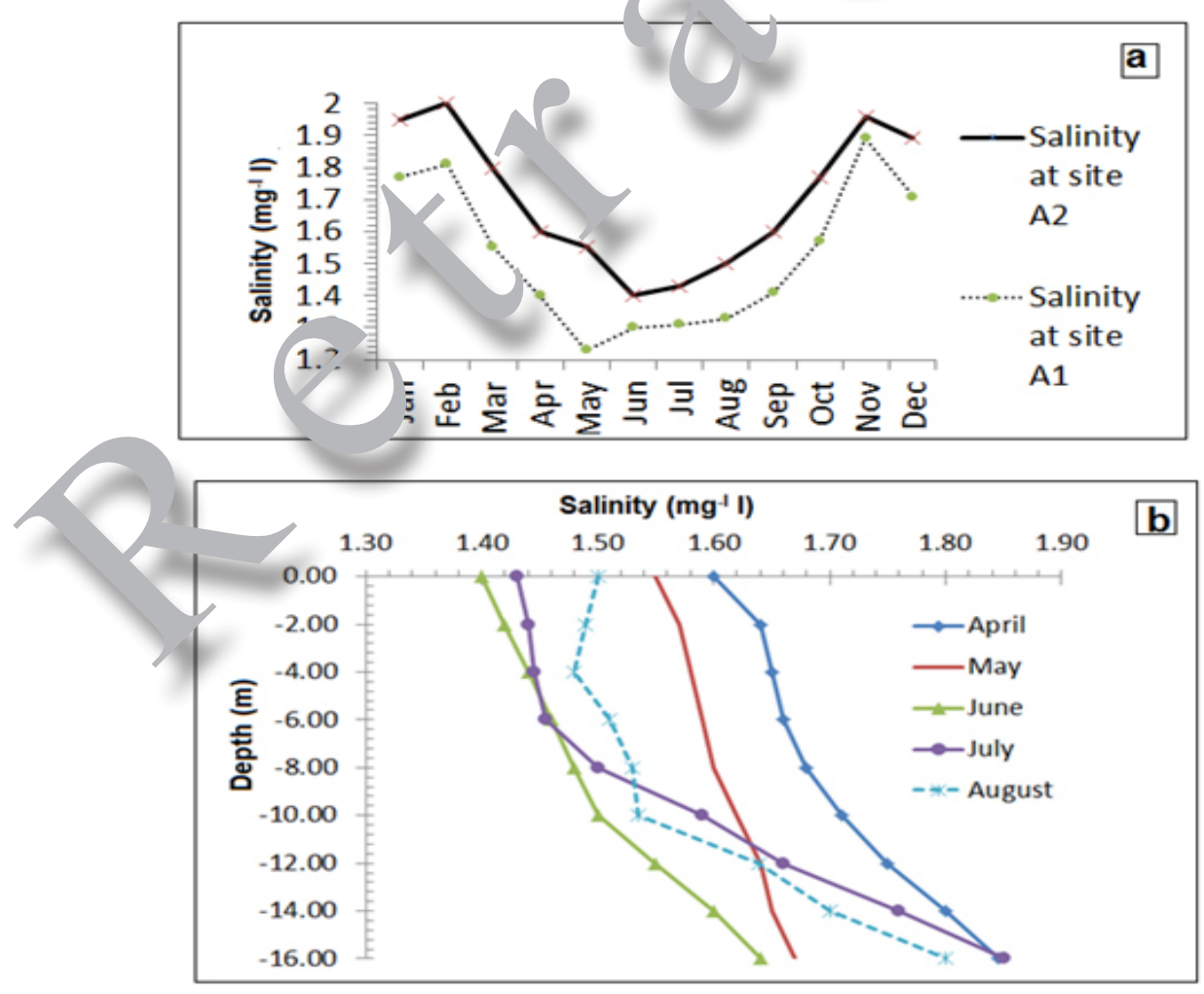

Fig.7: (a) Salinity at sites A2 and A1, (b) Depth profiles of salinity: April May, June, July and 

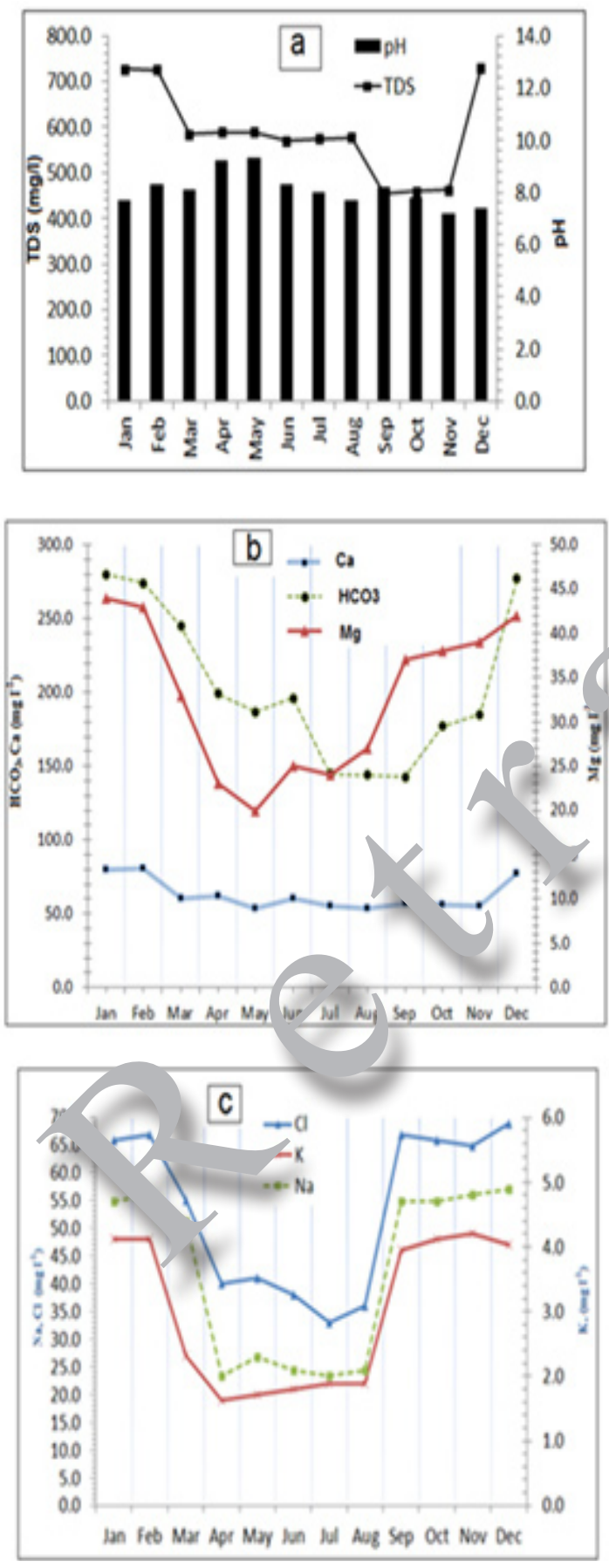

Fig. 8: (a) Monthly distribution of pH and TDS values in Sharhabiel Reservoir during the monitoring period(b) Fluctuations in $\mathrm{Ca}, \mathrm{Mg}$, and $\mathrm{HCO}_{3}$ levels of Sharhabiel Dam water during the study period (c) Fluctuations in $\mathrm{Na}$, $\mathrm{K}$, and $\mathrm{Cl}$ concentration of Sharhabiel Dam water during the study period uptake and sedimentation or through denitrification. Other sources of nitrate include animal waste, inputs from sewage, soil erosion, and domestic waste from cesspools and fertilizer runoff fror vlanted crops. In addition, the submergence of a large . ?a containing a large amount of plants and so's to. wing high rainfall may also contribute to th ? hight. $\mathrm{jO}_{3}-\mathrm{N}$ concentrations (Gaudet \& Muthu. 981 ). This is consistent with observat- that elevated values occurring in winter we e sorresponded with high rainfall and runoff contc ing $\mathrm{n}^{\text {; }}$ ate from adjacent agricultural $l_{c}{ }^{\prime} r^{\prime}$. Also, tht . vative high levels of nitrate are oit associated with spring months because of nitroy $f$ xation microbes. Decay of organi- esidues and decreased temperature (whic 7 reduces nitrogen fixation process) is other contr. 'ting $c$ luses to lower nitrate contents in the fall and su.... ner seasons.

Negative correlation was observed between $\left.\mathrm{N}^{\prime}\right)_{3}-\mathrm{N}$ and TP ( $\left.\mathrm{r}=-0.07\right)$ suggesting that different sources of these nutrients. In contrast to $\mathrm{NO}_{3}-\mathrm{N}$, $\mathrm{NH}_{4}-\mathrm{N}$ concentrations are lowest in winters and highest in fall (Fig.5, b) consistent with the negative correlation observed between both ions ( $r=$ " 0.28 ; Table1). This suggests that $\mathrm{NH} 4-\mathrm{N}$ is not probably associated with agricultural runoff and winter leaching. The decreased concentration of $\mathrm{NH} 4-\mathrm{H}$ in summer months is possibly attributed to the effect of higher temperature range during dry months, which led to increased $\mathrm{NH} 4-\mathrm{N}$ volatilization and to reservoir water dilution in wet months (Duyzer et al.19).

Levels of DRS at the reservoir showed low values with a mean concentration of $1.36 \mathrm{mg}$ ${ }^{-1} \mathrm{I}$ and $1.6 \mathrm{mg}^{-1} \mathrm{I}$ at sit $\mathrm{A} 2$ and A1, respectively (Fig. $5, b)$. Dissolved reactive silica could be attributed to chemical weathering of igneous rock on the country side areas (Abu Raka, 2004) and may probably to extensive fires of dry grasses and crop remains during summer at the eastern lands of Israel that carried by western wind and as minute input air sole. Additional possible sources of silica are the product of chemical weathering of minor oil shale and lensoidal beds of clay stone outcrops belongs to chalk marl formation (Fig.1).

$\mathrm{pH}$

The $\mathrm{pH}$ surface values did not show clear seasonally variations through the study period (mean 
8.3 and 8.1 at sampling sites A1 and A2, respectively). Between January and June, $\mathrm{pH}$ values were higher than 7.7 with maximum and minimum surface $\mathrm{pH}$ of 10.0 and 9.3 recorded in April and May 2013 at sampling site $A 1$ and A2, (Fig.6, a).

While winter months shows lowering in $\mathrm{pH}$ values due to stream floods containing large quantities of a dissolved basic ions are discharged into the reservoir, as a result of intense chemical weathering of carbonaceous formations of the upper Sharhabiel catchment (Ajun Highs), (Fig.1). The relative low levels of $\mathrm{pH}$ observed in the winter months are probably attributed to decreased photosynthetic rates in response to lower temperature and decreased in sunlight duration and intensity. According to Soares et al. (2008) the higher rate of phytoplankton growth is more likely associated with highly duration and intensity of light. In addition to the dilution effect of a large volume of water flowing into the Shrhabiel dam from upstrea' 1 in winter season which is highly rich in ammonic fertilizers, decaying of plant and organic fragments could be decreased the water pH values (Gaudet \& Muthuri 1981). Relatively high water, 't levels observed, particularly in dry nonths, are pı. arily related to increasing in phy - 'ankton gruwth, high temperature, sunlight intens, and nutrient availability. According to Fnnsica et al., „ 2010; 2011) and Kelly (2009), very r igh $r$, H values would dissolve and release metallic $\mathrm{mi}$ 'onutrie its, macronutrients, salts and ommonia from voir sediment which led al $s$ to , creasing $\mathrm{pH}$ values. Dominance of cyaı. 'vtes n summer was shown to be favored at high $\mathrm{pH}$, possibly because of the ability to use the bicarbonate ion as a carbon source (JVA, 2010). Due to the high plumbing rate and absence of water inflow in summer, neutralization of the water $\mathrm{pH}$ has no role in the reservoir.

The water column during 'e monitoring year showed homogeneity with no alтt. nces in $\mathrm{pH}$ readings, except in April and May r onths, $\uparrow$ 'values showed a minor variation with de $\mathrm{Ho}^{\prime}$ /ever, an average difference of $3.7: \mathrm{in}$ value was recorded between surface and ceer sr water (Fig. 6, b). The low $\mathrm{pH}$ values in the $\mathrm{d}_{\mathrm{t}}$ per $\mathrm{w}$ : ter of the reservoir can be attribi ter' to the s... _ rvness accompanied by the high $r_{\mathcal{A}}$ of sedimentation $0.041 \mathrm{~m}^{3} / \mathrm{y}(\mathrm{Al}$ Ansari 2010) anc 'he metabolic activities of the microon- nisms in the sediment.

Solu. $s$

levels of salinity, TDS and alkalinity, ᄀlso seasonally fluctuated over the 12-mounth s. No period, where highest values were generally cr rresponded with wet months and lowest values corresponded with dry months

Salinity did not vary with depth even during the minor thermal stratification; salinity showed no pattern of variation, this might be attributed to the relatively shallow depth of the dam. Very little difference was recorded during the course of the year. The average concentration of salt was $1.61 \mathrm{mg}$ $\mathrm{I}^{-1}$ at both sites (A2 and A1). The highest salinity was recorded in February at site $A 2$ where it reached $2.00 \mathrm{mg}^{-1} \mathrm{l}$, which coincided with an increase in the
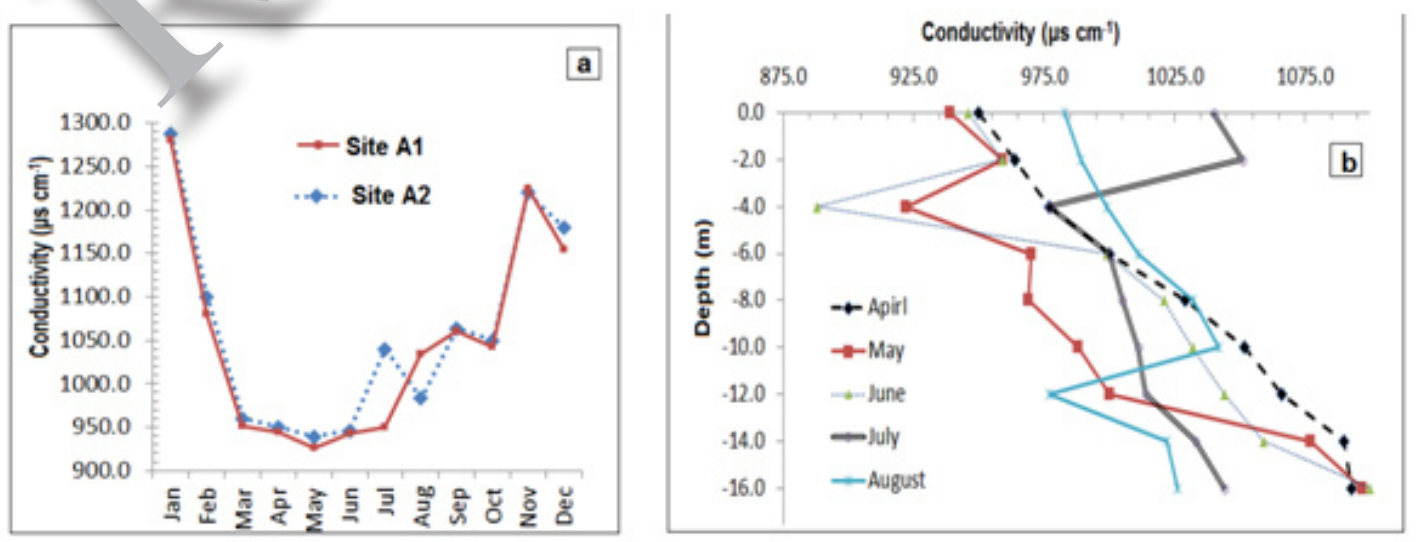

Fig.9: (a) Conductivity at sites A2 and A1, (b) Depth profiles of conductivity: April May, June, July and August 
reservoir inflow. At site A1, salinity was rather higher with a maximum value of $1.89 \mathrm{mg} \mathrm{l}^{-1}$ in November (Fig. 7, a, b).

The source of dissolved salts in the reservoir water seems to be mainly weathering of rocks, $\mathrm{Na}$ / $(\mathrm{Na}+\mathrm{Ca})$ plotted against TDS according to Gibbs (1970), demonstrated rock weathering as a dominant process (Fig.6, d), this agree with result of (Abu Ruka 2004).

Intense chemical weathering of the adjacent dam site carbonate rocks (limestone, dolostone, chalky marly limestone and silicified limestone) in response to high winter rainfall and runoff is the primary contributor to high TDS, alkalinity, and salinity values. Dry months shows lowering in TDS, alkalinity, and salinity values compared to that of other months are attributed to high rate of evaporation. Water evaporation in the reservoir accelerates mineral precipitation and reduces TDS levels (Fig.6, c and Fig. 7, a, b).

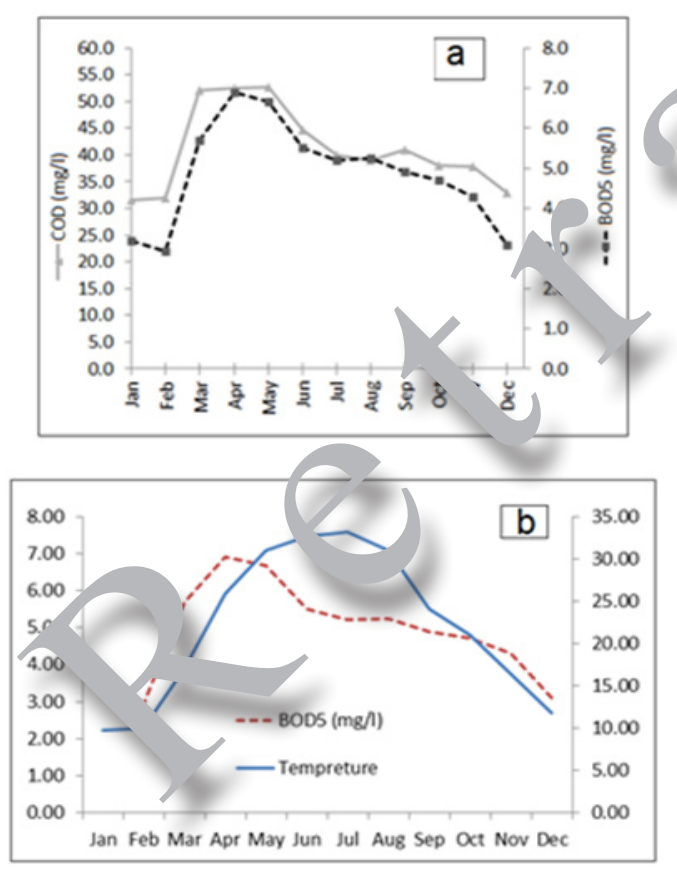

Fig. 10: (a) Monthly distribution of COD and $B_{5}$ values in Sharhabiel Reservoir during the monitoring period (b) Relation between $\mathrm{BOD}_{5}$ and temperature values of Sharhabiel Dam water during the study period
Slight variations in TDS levels between wet and dry months were found, in 2013 (Fig.8, a), the increase in water use for irrigation would increase turbidity levels and enhance re-suspension of settled particles and subsequent dissolution of precipitated salts. However, the higher rate of evaporation in summer is the probable cause for the lower TDS compared to that in winter.

Similar to TDS, the concentrations of $\mathrm{Ca}$, $\mathrm{Mg}$, and $\mathrm{HCO}_{3}$ in the reservoir water are primarily linked to leaching and evaporatior (. ๆ. 8, b). Relative to dry season, elevated levels of $\mathrm{Ca}$, and $\mathrm{HCO}_{3}$ were observed in winter period, in rt onse to leaching and decreased concurre th with s.e drier months.

The lower otues $^{\prime}$ heasured in dry months are attributed to un: iation of carbonate minerals foll ing an increase in temperatures and evaporatior. The similar distribution patterns in $\mathrm{Ca}, \mathrm{Mg}$, and $\mathrm{HC}$ suggest that these ions are prob Dly originated from similar sources (Abu Rake 2004, I:l- Radaideh 2014). Ca is positively correla $\mathrm{d} . \mathrm{h} \mathrm{Mg}, \mathrm{HCO}_{3}$, and TDS with $\mathrm{r}=0.66$, 0.89 , and 0.85 , respectively (Table 1 ), and believed have been derived from calcareous formations; th, 2 formations cover a significant portion of upper adi Ziqlab watershed area (Fig.1). In addition, $\mathrm{Ca}$ concentrations showed positive correlation with PO4 ( $r=0.40$; Table1) suggesting that phosphorite minerals (from phosphate-bearing strata which belong to ASL Formation) is another source of both $\mathrm{Ca}$ and $\mathrm{P}$. The distribution patterns in $\mathrm{Ca}, \mathrm{Mg}, \mathrm{HCO}_{3}$ and TDS show that they constitute a major poron of TDS in water. This is evident from the positively correlation coefficients between TDS and $\mathrm{Ca}, \mathrm{Mg}$, and $\mathrm{HCO}_{3}(r=0.85 ; \mathrm{r}=0.40 ; \mathrm{r}=0.81$; Table 1$)$

In contrast to $\mathrm{Ca}, \mathrm{Mg}, \mathrm{HCO}_{3}$, and TDS, monthly patterns in $\mathrm{Na}, \mathrm{K}$, and $\mathrm{Cl}$ contents of surface water of Sharhabiel dam also showed higher values in wet periods (Fig. 8, c).

During the winter seasons, their concentrations increased, and during warm water months, the concentrations fluctuate, but stay consistently lesser than that of the cold water months. These high levels that occurred in winter are 
likely attributed to slightly unmixing process following heavy rainfall with the reservoir water.

In addition, the relative highest levels observed in fall months are related to precipitation of carbonate minerals and subsequent prevalence of $\mathrm{Na}, \mathrm{K}$, and $\mathrm{Cl}$ salts. $\mathrm{Na}$ and $\mathrm{Cl}$ concentrations are positively correlated $(r=0.96)$ indicating that they were derived from a similar source (halite). Halite dissolution releases equal concentrations of $\mathrm{Na}$ and $\mathrm{Cl}$, but data showed deviations from 1:1 relation indicating that a fraction of $\mathrm{Na}$ is associated with anions other than $\mathrm{Cl}$. The average $\mathrm{Na} / \mathrm{Cl}$ molar ratio (of about 1.25) suggests that Na may have also been released from silicate-weathering and dissolution reactions (Meybeck 1987, Abu Ruka 2004). Weathering of $\mathrm{N}$-plagioclase (the igneous rocks in the surrounding area) is a potential contributor of $\mathrm{Na}$ in water.

While both $\mathrm{Na}$ and $\mathrm{Cl}$ showed similar monthly distributions to that of $\mathrm{K}$, they are negatively correlated with $\mathrm{K}$ (Table1). The correlation coefficient between $\mathrm{Na}$ and $\mathrm{K}$ is highly positive ( $r=0.93$, suggesting similar possible sources for both iol s. The possible source of $k$ ions, seem to be chemical weathering of k-feldspar and atmosphє... input from Dead Sea aerosol salts, particu.. v sylvite particles.

The relative low $\mathrm{K}$ co. entrations in Sharhabiel Dam water is probably ributed to adsorption by clay part. es and formation of secondary minerals (I 1r.thess 1982). In addition, the strong positive corre. inn etween $\mathrm{K}$ and other major is . $\quad \mathrm{NO}_{3}-\mathrm{N},(\mathrm{r}=0.68)$ (Table1) suggests that was robably derived from agricultural fertilize, 'Patay.. (al. 2008).

Sam, is of site A2 showing slightly higher values of total alkalinity and ranged between $490 \mathrm{mg}$ $\mathrm{I}^{-1} \mathrm{CaCO}_{3}$ and $680 \mathrm{mg} \mathrm{l}^{-1} \mathrm{CaCO}_{3}$ in May and February, respectively At site $A 1$ the minimum total alkalinity of $480 \mathrm{mg} \mathrm{l}^{-1} \mathrm{CaCO}_{3}$ and a maximum of $671 \mathrm{mg} \mathrm{l}^{-1} \mathrm{CaCO}_{3}$ were recorded in May and February, respectively. Total alkalinity showed relatively higher values throughout the study year with an average of 552 $\mathrm{mg} \mathrm{l}^{-1} \mathrm{CaCO}_{3}$. The two sites showed increasing levels of alkalinity during the wet season from October to March (Fig.6, c)
The mean alkalinity of the reservoir was 552.0 as $\mathrm{mg}^{-1} \mathrm{C} \mathrm{CaCO}_{3}$, which highly correlates with salinity and conductivity $(r=0.86 ; r=0.60)$. This result agreed with previous work in Wadi Al-Arab Dam reservoir (Saadoun et al., 2008, 2010). The ratio of total alkalinity: conductivity of 0.53 established at the reservoir is in close agreement with a ratio of 0.50 computed by Kotut et al. (1999) for a number of MENA reservoirs. Levels of plkalinity showed an increase in the wet season 1 . - omparison to the dry season due to engagemer.. 'catchment soil through erosion from Ziqla , wadı nd their tributaries.

Conductivity alue, in the reservoir were generally high; with a ital mee ${ }^{+}$of 1054.6 is cm ${ }^{1}$ and no pattern of perioc. . ig. 9 , a).

In the st season, little increase in conductivity level $u_{\ldots}$ observed in rainy months whicr might be attributed to the erosion of catchment soil $1 \mathrm{Jm}$ the ziqlab wadi. Conductivity values did not sh. Jnificant variation with depth (Fig.9, b), a condition that indicates a thermocline of very - $r$ duration. This indicates the homogeneity of the cr $\epsilon_{1}$ nical composition of the reservoir water at both ampling sites. The reservoir conductivity values were higher than those reported by Saadoun et al., (2010) in Wad Al-Arab dam reservoir NW Jordan. In contrast with other lakes and reservoirs located in MENA region, conductivity values of Sharhabiel dam reservoir are rather high (Al-Tanni 2011, Coche 1974, Hall et al. 1977, Temperas et al. 2000).

Seasonal variations in organic matter content $\left(\mathrm{COD}\right.$ and $\left.\mathrm{BOD}_{5}\right)$ were also apparent, with peaks generally occurring in spring through early fall months (Fig.10, a).

The relative high concentrations of COD and $\mathrm{BOD}_{5}$ were corresponded with high algal growth. A possible explanation for the seasonally low levels of COD in winter is due to reduced phytoplankton activity in response to low temperature and sunlight intensity (Fig.10, b). Furthermore, the high correlation coefficient between $\mathrm{COD}$ and $\mathrm{BOD}_{5}$ $(r=0.94)$ suggests that both are associated with similar sources and may probably be related to agricultural runoff, improper waste disposal, and wastewater effluent discharged into the reservoir. 


\section{ACKNOWLEDGMENTS}

The author gratefully acknowledges use of the services and facilities at Yarmouk University,
Jordan and data provided by Jordan Valley Authority. Appreciation is extended to the staff of Sharhabiel Dam reservoir for their great help and support.

\section{REFERENCES}

1. Abu-Rukah, Y., \& Ghrefat, H., Ion chemistry of waters impounded by the Sharhabiel dam, Jordan, and weathering processes. International Journal of Environmental Pollution. 21(3), 263-276 (2004).

2. Agrar \& Hydrotecnik, National Water Resources Master Plan of Jordan. 8 Volumes, Essen, Hannover (1997).

3. Al-Ansari N., \& Shanti A., Siltation of three small reservoirs in Jordan, Al-Manara, 12 (2):10-26 (2006).

4. Al-Handal A.Y., \& Saadoun I., Phytoplankton composition and physical-chemical features of a hypertrophic reservoir in North Jordan: King Talal Reservoir, River Idrobiology, 40; 305-320 (2001).

5. Al-Taani, A., Seasonal variations in wat quality of Al-Wehda Dam north of Jordan and water suitability for irrigation in ,ummer. Arabian Journal of Geosciences, a、 10.696 1007/s12517-011-0428-' (2011).

6. American Public Health $A$ ciation (AP $-1 A$ ), American Water Works Asso tion (AWWA) and Water Environment federa...un (WEF). Standard metho ds ' $r$ r the examination of water and wastel "icer (20 h ed.). Washington DC: $\triangle \mathrm{PHA}$ (1998)

7. Fasny P, Teeter L, Lockaby BG, Flynn KM, ?nd $u$ e characteristics and water quality: a $m_{1}$ sdolvyy . $r$ valuing of forested buffers. Enviı, Manage 26: 153-161 (2000).

8. Bataynt ., A., Al-Momani, I., Jaradat, R., Awawdeh, M., Rawashdeh, A., \& Ta'any, R. Weathering processes effects on the chemistry of the main springs of the Yarmouk Basin, north Jordan. Environmental Hydrology, 16; 20 (2008).

9. Bender, F., Geology of Jordan, Borntraeger, Berlin (1974).

10. Boyd C.E., Water chemistry and plankton in unfertilized ponds in pastures and in woods, Trans Am. Fisher. Soc., 105: 634-436 (1976).
11. Boyd C.E., Water quali' ${ }^{\prime}$ in ponds for aquaculture, Birmingha, Publ. Co., Birmingham, Al. pp 482.

12. Branco, C. W. C., Rocha, M I. A., F. 'n, G. F. S., Gomara, G.A., \&Filippo, Limr ological features of Funil Ronorvoir (Ru, orazil) and indicator propertic $\mathrm{S}$ of otifers and cladocerans of the zooplank in cor munity. Lakes \& Reservirc: Reseaı . .d Management, 7; 87-92 - ר2).

13. Carlson Rt, A tiophic state index for lakes. l imnol Oceanugr 22(2): 361-369 (1977).

14. Cheng XY, LiSJ, An analysis of the evolvement roces es of lake eutrophication and their cı. teristics of the typical lakes in the middle and lower reaches of Yangtze River. Chin Sci Bull 51(13): 1603-1613 (2006).

15 Cloot, A., \& Ros, J. C. Modeling a relationship between phosphorus, $\mathrm{pH}$, calcium and chlorophyll-a concentration, Water $S A, 22$; 49-55 (1996).

16. Coche A.G., Limnological study of a tropical reservoir. [In:] Man Made Lakes: The Accra Symposium, Eds., Obeng, L.E., pp. 116-122 (1974).

17. Dillon, P. J., \& Rigler, F. H. The phosphoruschlorophyll relationship in lakes. Limnology and Oceanography, 19; 767-773(1974).

18. Dodds, W. K. Misuse of inorganic N and soluble reactive $\mathrm{P}$ concentrations to indicate nutrient status of surface waters. Journal of the North American Benthological Society, 22; 743 171-181 (2003).

19. Dodds, W. K. Nutrients and the"dead zone": the link between nutrient ratios and dissolved oxygen in the northern Gulf of Mexico. Frontiers in Ecology and the Environment, 4; 211-217 (2006).

20. Dokulil MT, Herzig A, An analysis of long-term winter data on phytoplankton and zooplankton in Neusiedler See, a shallow temperate lake, Austria. AquatEcol 43:715-725DOI10.1007/ s10452-009-9282-3 (2009). 
21. Duyzer, J.H., Verhagen, H. L. M. \& Erisman, J. W. The deposition of acidifying substances at the Asselsche Heide(in Dutch), MT-TNO Rep. R 89/029, Delft, The Netherlands (1989).

22. El-Radaideh, N., Al-Taani, A. A., Al-Momani, T., Tarawneh, K., Batayneh A., and Taani, A., Evaluating the potential of sediments in Ziqlab Reservoir (northwest Jordan) for soil replacement and amendment. Lake and Reservoir Management, 30; 32-45 (2014). http://dx.doi.org/10.1080/10402381.2013.8 70263

23. Fandi, K. G., Qudsieh, I.Y., Muyibi, S. A., Massadeh, M. "Water Pollution Status Assessment of King Talal Dam, Jordan." Adv. Environ. Biol. 3(1): 92-100 (2009).

24. Ferrier, R. C., Edwards, A. C., Hirst, D., Littlewood, I. G., Watts, C. D., \& Morris, R. Water quality of Scottish rivers: spatial and temporal trends. Science of the Total Environment, 265; 327-342 (2001).

25. Fonseca, R. M., Barriga, F. J., and Conceiçã ), P. I., Clay minerals in sediments of Portuguese reservoirs and their significa se as weathering products from over-er ed soils: A comparative study of the Maranha, Monte Novo and Divor Reservo * , South Port , al). International Journal of $E_{2}$ th Science, 99; 1899-1916 (2010). http://dx.dc ar //10.1007/ s00531-009-0488 -

26. Fonseca, R., B arriya, F. J. A. S., \& Fyfe, W. S. Suitabilit, for = jricultural use of sf nts from the iviaranhão Reservoir. In И. A. ( Fragoso \& M. L. Beusichem (Eds.), - tim. .. n n riant nutrition (pp. 665-671). Do, echt: Kluwer Academic Publishers (1993).

27. Fonsecd, R., Canario, T., Morais, M., and Barriga, F., Phosphorus sequestration in Fe-rich sediments from two Brazilian tropical reservoirs. Applied Geochemistry, 26; 16-7 (2011). http://dx.doi.org/10.1016/j. apgeochem.2011.04.017

28. Forsberg, C., \& Ryding, S. O. Eutrophication parameters and trophic state indices in 30 Swedish waste-receiving lakes, Archiv fuer Hydrobiologie, 89; 189-207 (1980).

29. Gaudet, J. J., \& Muthuri, F. M. Nutrient relationships in shallow water in an African Lake. Lake Naivasha. Oecologia, 49; 109-118
(1981).

30. Guildford, S. J., Hendzed, L. L., Kling, H. J., Fee, E. J., Robinson G. G. C., Hecky, R. E., et al. Effects of lake size on phytoplankton nutrient status. Canadian Journal of Fisheries and Aquatic Sciences, 51; 2769-2786 (1994).

31. Hall A., Valente I.M., Davies B.t The Zambezi Reiver in Mozambique: the shysı chemical status of the middle and 'ower \& mbezi prior to closure of the Cabo. sa Dam, Freshwater. Biol. . 7-206 (1977).

32. Hirsch, R.M., F.A. Har ilton, T.L. Miller. "U.S. Geologicá Sur y perspective on water-c dity monitorıng and assessment." Journal o. -nvironmental Monitoring 8: 512518 (2006).

33. 17. J, Hashemite Kingdom of Jordan and GTZ (2008a Water Resources in Jordan. National "sste Water Plan

34. Joraan Valley Authority (1965) Completion Report of Ziqlab Dam, JVA, Govt. of Jordan, Kelly, S. Report on the Green and Watch Lakes sewage contaminated seepage detection study (p. 23). Kamloops, British Columbia: Environmental Protection Division, Ministry of Environment (2009).

36. Kotut K., Krienitz L., Muthari M., Temporal changes in phytoplankton structure and composition at the Turkwel Gorge Reservoir, Kenya. Hydrobiologia, 368: 41-59 (1998).

37. Levine, S. N., \& Schindler, D. W. Influence of nitrogen to phosphorus supply ratios and physicochemical conditions on Cyanobacteria and phytoplankton species composition I the Experimental Lake Area, Canada. Canadian Journal of Fisheries and Aquatic Sciences, 56; 451-466 (1999).

38. Macdonald, M., East Bank of Jordan Water Resources, Report 4, Storage on the Wadi Ziqlab, Jordan (1965a).

39. Macdonald, M., Wadi Ziqlab Dam, Geological Report on the Upper Dam Site, Jordan (1965b).

40. Madison, K. R. Diagnostic Feasibility Study Lake Kampeska(p. 107). Codington County, South Dakota: South Dakota Department of Environment and Natural Resources (1994).

41. Matthess, G. The properties of groundwater 
(pp. 215-255). New York: John Wiley and Sons (1982).

42. Meybeck, M. Global chemical weathering of surficial rocks estimated from river dissolved loads. American Journal of Science, 287; 401-428. Press, San Diego, CA (1987).

43. MWI, Ministry for Water and Irrigation, Water for Life - Jordan's Water Strategy 2008-2022 (2009).

44. Pridmore, R. D., Vant, W. N., \& Rutherford, J. C. Chlorophyll-nutrient relationships in North Island lakes (New Zealand). Hydrobiologia, 123; 181-189 (1985).

45. Rhee G.I., Effects of environmental factors and their interactions on phytoplankton growth, Advances in Microbial Ecology, 6: 33-74 (1982).

46. Richardson CJ, King RS, Qian SS, Vaithiyanathan P, Qualls RG, Stow CA, Estimating ecological thresholds for phosphorus in the Everglades. Environ Sci Technol 41(23):8084-8091 (2007).

47. Saadoun I, Batayneh E, Alhandal A, Hindi th M. Physicochemical features of Wadi : Arab Dam (reservoir), Jordan, International Journal of Oceanography and H'robiology, Vol. XXXIX, No.4, pp. 189-203 (20. '`. DOI 1 0.2478/v10009-010-00:7-

48. Saadoun, I., Bataineh, _ Al-Handal, A. Y. The primary production cc. vition of Wadi Al-Arab Dam (Remrvoir), Joruan. JJBS, 1; 67-62 (2008).

49. Shatnawi, A., tydro sgical and Hydro ch-mical Study foı - _.ab Dam, MSc. Thesis,
Al al-Bayt University, Jordan (2002).

50. Soares, M. C. S., Marinho, M. M., Huszar, V. L. M., Branco, C. W. C., \& Azevedo, S. M. F. O. The effects of water retention time and watershed features on the limnology of two tropical reservoirs in Brazil. Lakes \& Reservoirs: Research and Management, 13; 257-269 (2008).

51. Temponeras M., Kristianser, MoustakaGouni M., Seasonal variatic i in $\uparrow$ toplankton composition and physical-c emical . Lures of the shallow lake Dorani, Ma Joni ,, Greece, Hydrobiologia, 4? "09-122 (2000)

52. Voros $L$ and Parisak J. Phytoplankton biomass and ch. rophy' -a in some shallow lakes ר central Euı re. Hydrobiologia 215: 111-1، GMENTS (1991)

53. Water Autr, itv of Jordan (WAJ ), The North rdan Water Resources Investigation Project, Amman, Jordan (1989)

54. Wetz', R. In: Limnology; Lake and River Łuvoystems, Third Edition. Academic (2001)

Wetzel, R. G. Limnology. Orlando, Florida: Saunders College Publishing (1983)

56. Yang X, Wu X, Hao H, He Z, Mechanisms and assessment of water eutrophication. Journal of Zhejiang University of Science 9(3):197-209 (2008).

57. Zhao, P., Tang, X., Tang, J., \& Wang, C. Assessing water quality of Three Gorges Reservoir, China, over a five-year period from 2006 to 2011. Water Resources Management, 27; 4545-4558 (2013). 